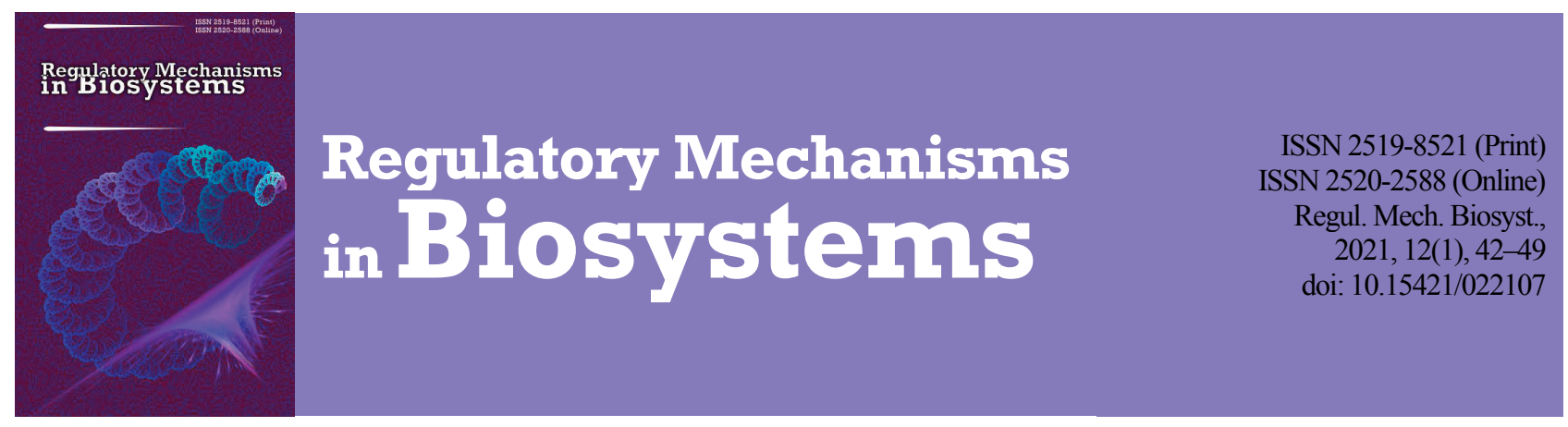

\title{
California's endemic Cornus sessilis in Ukraine
}

\author{
S. V. Klymenko*, A. P. Ilyinska*, A. V. Kustovska**, N. V. Melnychenko** \\ *M. M. Gryshko National Botanical Garden of the National Academy of Sciences of Ukraine, Kyiv, Ukraine \\ **Dragomanov National Pedagogical University, Kyiv, Ukraine
}

Article info

Received 10.01.2021

Received in revised form 15.02.2021

Accepted 17.02.202

M. M. Gryshko National Botanical Garden

of the National Academy

of Sciences of Ukraine,

Timiryazevskaya st., 1

Kyiv 01014, Ukraine.

Tel.: +38-097-673-26-25.

E-mail:

cornusklymenko@gmail.com

Dragomanov National Pedagogical University

Pyrogova st., 9 ,

Kyiv, 01601, Ukraine

Tel.: + 38-044-234-11-08.

E-mail:shef-npu@ukr.net

\begin{abstract}
Klymenko, S. V., Ilyinska, A. P., Kustovska, A. V., \& Melnychenko, N. V. (2021). California's endemic Cornus sessilis in Ukraine. Regulatory Mechanisms in Biosystems, 12(1), 42-49. doi:10.15421/022107
\end{abstract}

Global climate change and increased land use lead to the loss of biodiversity at all levels of the organization of living organisms ecosystems, species, landscape population, genetic, molecular biological levels, etc. The reaction of plants to anthropogenic impact, according to experts, may be even stronger than postglacial changes. A shift in the thermal isotherm will cause the plants to either move and adapt, or disappear. Endemic species that make up "biodiversity hotspots" require special attention. Cornus sessilis Torr. ex Durand, the object of our research, is part of one of these points - the California Floristic Province. Researchers are now focusing their efforts on developing a climate change - related biodiversity management strategy. In the case of the threat of extinction of the species in nature, there is a important method of preserving it in culture (ex situ). M. M. Gryshko National Botanical Garden at the National Academy of Sciences of Ukraine (the NBG) pays great attention to the introduction of rare endemic species from the different geographical and floristic regions of the world. The gene pool of Cornus L. s. 1. in the NBG consists of more than 30 species and 40 cultivars including the insufficiently researched and little-known Californian endemic C. sessilis. In Europe, it has been grown since 2017 only in Chateau Perouse Botanic Gardens (Saint-Gilles, France) and in Ukraine only the NBG has it. In this article we evaluate the life cycle of the development $C$. sessilis under conditions of introduction different from the conditions of its natural area. To do this, we used the classic traditional methods of the research on the process of introduction, in particular, botanical plant identification, visual observation, phenology, comparative morphology and biometrics. Morphological descriptors (life form, colour and texture of bark, leaf shape, pubescence character, structure of generative and vegetative buds, inflorescences, flowers, fruits and endocarp) of $C$. sessilis genotypes introduced to the NBG are identical to those of plants from their natural habitats. The weight of fruits and endocarps were determined by us for the first time. The results of biometric analysis of the size of leaves and fruits showed that the plants of $C$. sessilis grown in the NBG had the larger leaf blades, but the smaller fruits as compared to those in the wild. In the NBG the plants underwent a full cycle of seasonal development (from the deployment of buds to the leaf fall, inclusive) for 229 days. In general, the phenological strategy of $C$. sessilis genotypes introduced in the NBG corresponds to that of other species of Cornus s. str., including C. mas L. Our results indicate that C. sessilis, California's rare endemic species new to Ukraine, has adapted to the new conditions - the plants bear fruits and produce seeds. The experience of successful introduction makes it possible to cultivate a new species to expand the diversity of food, medicinal and reclamation plants of the family Cornaceae as well as the use in synthetic breeding to obtain new cultivars with valuable biological and economic properties. Cornus sessilis compatibility test as rootstocks for other species is important for clarifying the theoretical issues of family ties of species Cornaceae and practical - for widespread reproduction of the required cultivars $C$. mas breeding in the NBG on a potentially compatible rootstock $C$. sessilis.

Keywords: miner's comel; plant introduction; climate change; phenology; biometrics.

\section{Introduction}

Botanical gardens have been the main centers for the introduction, acclimatization and cultivation of the alien and native, rare and widespread plant species since the 16th century. In the second half of the 20th century, they also began to operate as important centers for the protection and conservation of biodiversity, especially rare endemic and relict plant species worldwide, and Ukraine is not an exception (Kondratyuk \& Ostapko, 1990; Primack \& Miller-Rushing, 2009; Krishnan \& Novy, 2016). Botanical gardens now have a unique role to play in the climate change projects that cannot be carried out elsewhere, due to their resources, including controlled growing conditions, living collections with extensive taxonomic representations, and the ability to carefully document observations (Primack \& Miller-Rushing, 2009; Faraji \& Karimi, 2020). Particular attention is increasingly paid to monitoring the seasonal development of varieties of aboriginal and introduced plants, as it reflects the effect of the climate change on large territories (Chmielewski, 1996; Menzel \& Fabian, 1999; Menzel, 2000; Chmielewski \& Rotzer, 2001; Primack \& Miller-Rushing, 2009).
Research of problems of introduction, acclimatization and adaptation of plants, preservation and replenishment of gene pool of endemic, relict, rare and endangered species, selection of new cultivars and forms, transfer of plants of new species from in situ to ex situ is the main focus of the scientific activity of the M. M. Gryshko National Botanical Garden of the National Academy of Sciences of Ukraine (the NBG). Currently, the NBG collection of the living plants of the temperate zone of Eurasia includes about 10 thousand species. The gene pool of cornel (Cornus s. 1.) which began to form in the 1960s has an important place in the collection (Klymenko et al., 2017, 2019). As of now plants of Cornel genus, commonly known as dogwoods, in the NBG comprise more than 30 species and 40 cultivars and forms (Klimenko, 1990, 2004; Klymenko et al., 2017, 2019). Among the rare species in the collection, there is the littleknown endemic of the North-Western America $C$. sessilis Torr. ex Durand - 'sitting dogwood' or as it is called 'miner's dogwood' or 'blackfruit cornell' or 'blackfruit cornelian cherry' because of the almost black colour of its fruit.

California's rare endemic C. sessilis together with European C. mas, three Asian species (C. officinalis Siebold \& Zucc., C. chinensis Wangerin 
and C. eydeana Q. Y. Xiang \& Y. M. Shui) and African $C$. volkensii Harms comprise a part of the subgenus Cornus or the genus Cornus L. s. str. in the classic genus systems (Eyde, 1988). The results of modern molecular biological studies have confirmed the monophyletic nature of the genus Cornus s. 1. (Xiang et al., 2006, 2008; Xiang \& Thomas, 2008; Yu et al., 2017). Within it, the authors identified four main clades, the species of which also differ in their morphological features, particularly: (1) species with red fruits and four large bracts (subgenus Cynoxylon (Raf.) Raf. and Syncarpea (Nakai) Q. Y. Xiang), (2) herbaceous plants with small complex cymoid inflorescences and four petal-like bracts (subgenus Arctocrania (Endl.) Rchb.), (3) plants with white, blue or blueblack fruits, open cymoid inflorescences with small early falling bracts (subgenus Kraniopsis Raf., Yinquania (Y. M. Zhu) Q. Y. Xiang \& Boufford, and Mesomora Raf.) and (4) plants with red, yellow or purple-black fruits, umbrella-shaped tassels and four scaly bracts (subgenus Sinocornus Q.Y. Xiang, Afrocrania (Harms) Wangerin and Cornus). The last clade included six species: $C$. sessilis together with $C$. mas, $C$. officinalis, C. eydeana, C. chinensis and $C$. volkensii. They formed a related group, the taxonomic rank of which was defined as the subgenus Cornus (Eyde, 1988; Xiang et al., 2005, 2006, 2008) or the genus Cornus s. str. Its diagnostic morphological descriptors are as follows: tree life form, inconspicuous small bracts, the presence of distinct peduncles, umbrella or umbrella-shaped inflorescence and endocarp (fruit stones), permeated with round-ovate cavities. Such cavities are not observed in any other species of the genus Cornus s. 1. (Manchester et al., 2010). In fact, molecular studies have confirmed the phylogenetic hypothesis of Eyde (1988), developed by analyzing the morphological features and fossil remains of dogwood species (Xiang et al., 2006; Atkinson et al., 2016). In the genus Cornus s. str. (or subgenus Cornus) four species are most related morphologically and genetically: C. mas, C. officinalis, C. eydeana and C. chinensis. They form a separate clade. Cornus sessilis which is somewhat phylogenetically distant from them forms its own clade, a sibling to the previous group. Cornus volkensii is even more separated and forms an independent clade, a sibling to other species. These three groups of species have disjunctive habitats. The natural distribution of the first four species is concentrated in Eurasia, C. sessilis exists only on the North American continent, and C. volkensii- only in Africa.

Cornus sessilis has a very narrow natural range. The species is localized in the continental United States and bounded by Northern California (ridges Klamath Range and Cascade Range), northern Sierra Nevada, and southern Oregon (the Siskiyou Mountains) (Murrell \& Poindexter, 2016). The species is characteristic of the shaded, in whole or in part, ecotopes of wet ravines, river banks and wetlands; $60-2,000 \mathrm{~m}$. Cornus sessilis plants are tolerant to the composition and $\mathrm{pH}$ of the substrate: they grow on light (sandy), medium (loamy) and heavy (clay) soils which have acidic (5.5), neutral or alkaline (7.3) $\mathrm{pH}$ response, but prefer well-moistened ecotopes (https://pfaf.org; https://ucjeps.berkeley.edu; www.calflora.org). It is characterized by $2 n=20$, in contrast to $C$. mas and $C$. officinalis which have $2 \mathrm{n}=18$ (Xian \& Eyde, 1995). In 2018, the species was included in the Red List of the Threatened Species of the International Union for Conservation of Nature (www.iucnredlist.org/species/130049866/130049869) as being in a stable condition but needs constant monitoring due to the high fragmentation of the population and gradual decline of the adult plants. It is included in the database of a UK-registered charity and linked to the 'Plants for the Future' (PFAF) website which aims to provide information on environmentally sustainable gardening to create a harmonious ecosystem with minimal damage to the environment and high productivity (https://pfaf.org). In the USA, this species is cultivated in nurseries, for example, in four of the Californian ones which specialize in growing a range of native species for their use in horticulture, garden design and landscaping (https://calscape.org). According to the Botanic Gardens Conservation International, live C. sessilis plants are available in 10 botanical gardens around the world (www.bgci.org). Four specimens grow in the Chateau Perouse Botanic Gardens (Saint-Gilles, France) in the Plants of California experimental garden created in 2017 (www.chateauperouse.com).

In Ukraine $C$. sessilis is known only in the NBG, where it was introduced to in 2003 (Fig. 1-3). The plants were grown from the seeds obtained from California, USA. Due to the extremely frosty (min. tempera- ture $-20.4{ }^{\circ} \mathrm{C}$ ) winter with sharp temperature differences in 2009-2010, the aboveground part of the plants froze but the root system was preserved. Subsequently, the plants recovered and in 2018 bloomed for the first time. Only a few fruits had reached full maturity. In 2019, individual plants of $C$. sessilis have also gone through the entire cycle of seasonal development.

The purpose of our work is to conduct initial testing of the condition of $C$. sessilis introduced to the NBG based on the analysis of morphological descriptors, quantitative traits of leaves, fruits and endocarp, as well as phenophases of seasonal development of plants.

The main average annual climatic indicators of the region of natural growth of $C$. sessilis on the example of the city of Sacramento (California, USA) and places of cultivation of its plants on the example of the city of Kyiv are given according to the Climate data for cities worldwide (https://en.climate-data.org). Meteorological conditions of Kyiv during the vegetation period of 2019 (Fig. 4) are given according to the archive of the meteorological records (https://rp5.ua/Weather_in_Kiev,_Zhuliany).

Kyiv is the capital of Ukraine, located on the border of Polissya and Forest-Steppe on both banks of the Dnipro river in its middle course. The geographical coordinates of the city are as follows: $50^{\circ} 27^{\prime} 17^{\prime \prime} \mathrm{N}$, $30^{\circ} 31^{\prime 2} 6^{\prime \prime}$ E. The climate of Kyiv is temperate-continental, with mild winters and warm summers (Table 1). The coldest period during the observation period in the NBG was 1942 with the average annual temperature of $+5.1^{\circ} \mathrm{C}$. The warmest year was 2019 with an average annual temperature of $+10.6^{\circ} \mathrm{C}$. In the last $100-120$ years, the air temperature in Kyiv has had a tendency to increase similarly to the Earth in whole. During this period, the average annual air temperature in Kyiv increased by about $1.5^{\circ} \mathrm{C}$. Precipitation is distributed more or less evenly throughout the year (Table 1). The mean number of days with precipitation is almost 160 . The main soil type is dark grey podzolic (Osadchyy et al., 2010).

Sacramento is the capital and one of the oldest cities in California, located in the western United States at the confluence of the American River with the Sacramento River from which it got its name. The city was founded in 1848 during the California gold rush. The geographical coordinates of the city are as follows: $38^{\circ} 34^{\prime} 54^{\prime \prime}$ N 121 $29^{\prime} 40^{\prime \prime}$ W. Sacramento's climate is almost Mediterranean with mild and rainy (November to March) winters and hot and sunny summers (Table 1). In winter the temperature rarely drops below $-4{ }^{\circ} \mathrm{C}$, and in summer it can rise higher than $+40{ }^{\circ} \mathrm{C}$. Precipitation is not abundant, amounting to $459-480 \mathrm{~mm}$ per year, falling mostly in winter (https://en.climate-data.org).

\section{Material and methods}

The research was carried out in the NBG (South-Eastern part of Kyiv, low Pechersk slopes of the Kyiv Upland, Zvirynets tract). To determine the peculiarities of acclimatization in the conditions of introduction of California's endemic $C$. sessilis, we compared the main climatic parameters of Kyiv and the city of Sacramento (California, USA) (Table 1).

\section{Table 1}

Climate-data of Kyiv (Ukraine) and Sacramento (California, USA)

\begin{tabular}{lcc}
\hline \multicolumn{1}{c}{ Parameters } & Kyiv & Sacramento \\
\hline Altitude, $\mathrm{m}$ & 186 & 16 \\
Climate & cold and temperate & warm and temperate \\
Mean annual temperature, $\mathrm{t}^{\circ} \mathrm{C}$ & 7.7 & 15.9 \\
Warmest month, $\mathrm{t}^{\circ} \mathrm{C}$ & July, 19.6 & July, 24.1 \\
Coldest month, $\mathrm{t}^{\circ} \mathrm{C}$ & January, -5.6 & January, -7.4 \\
Annual precipitation & during the year & mostly in winter \\
Rainfall per a year, $\mathrm{mm}$ & 640 & 459 \\
Most of the precipitation, $\mathrm{mm}$ & $\mathrm{July}, 86$ & Januar, 98 \\
Driest month, mm & March, 37 & July, 1 \\
\hline
\end{tabular}

Objects of research: genotypes of $C$. sessilis grown in the NBG from the seeds obtained from California (Sierra Seed Supply, USA). The paper presents the results of the study conducted during 2019.

To identify seed-grown plants, we used the species protolog (Durand, 1855), its morphological description (Murrell \& Poindexter, 2016), other literature data (Weaver, 1976; Eyde, 1988), and digitized herbarium specimens from the collections of three herbariums: New York Botanical Garden (sample collection JM Bigelow: near Grap Valley, barcode 2505696 (http://sweetgum.nybg.org/science/vh/specimen-details/?irn=2734560); 
and HN Bolander: s.n., Forest Hill, barcode 2505699 (http://sweetgum.nybg.org); Harvard University Herbaria \& Libraries (barcode 00075359, specimens from four authors mounted on one sheet: H.N. Bolander 4555, H. Mann, Dr. J. M. Bigelow and H. Pratten (https://s3.amazonaws.com/huhwebimages/ED5FC015F6794F1/type/full 775359.jpg); Herbarium of the Muséum National d'Histoire Naturelle (MNHN: Collection Vascular plants (P), Paris, France): sheet with specimens of two collections, barcode P04539375 (http://coldb.mnhn.fr/catalognumber/mnhn/p/p04539375). Herbarium specimens housed in the National Museum of Natural History (MNHN) are part of the collection of E. M. Durand donated to the Museum in $1868 \mathrm{https}: / /$ collections.nlm. nih.gov/catalog/nlm:nlmuid-101200035-bk). The condition of the genotypes of plants grown in the NBG was assessed by visual observation and comparison of the biometric indicators of their leaves and fruits and simi- lar literature data on the plants from the natural groups (Murrell \& Poindexter, 2016). We examined the following quantitative characteristics of the plants: length and width of the leaf blade; petiole length; length, diameter and weight of the fruit and endocarp. Quantitative indicators were processed by the methods of variation statistics using the software package PAST 2.10 (Hammer et al., 2001). The main descriptors were used to characterize the samples of leaves, fruits and endocarp: mean (M), standard deviation $(\mathrm{SD})$, minimum and maximum value (min - max) and coefficient of variation $(\mathrm{V}, \%)$. The normality of the frequency distribution of each trait was checked using the W-test Shapiro-Wilk. Most of the characteristics had a normal distribution, with just one, the length of the petiole, deviating from normal (Shapiro - Wilk test $\mathrm{W}=0.89, \mathrm{P}<0.05$ ). The level of variability of the quantitative traits was assessed according to Mamayev's classification (1975).

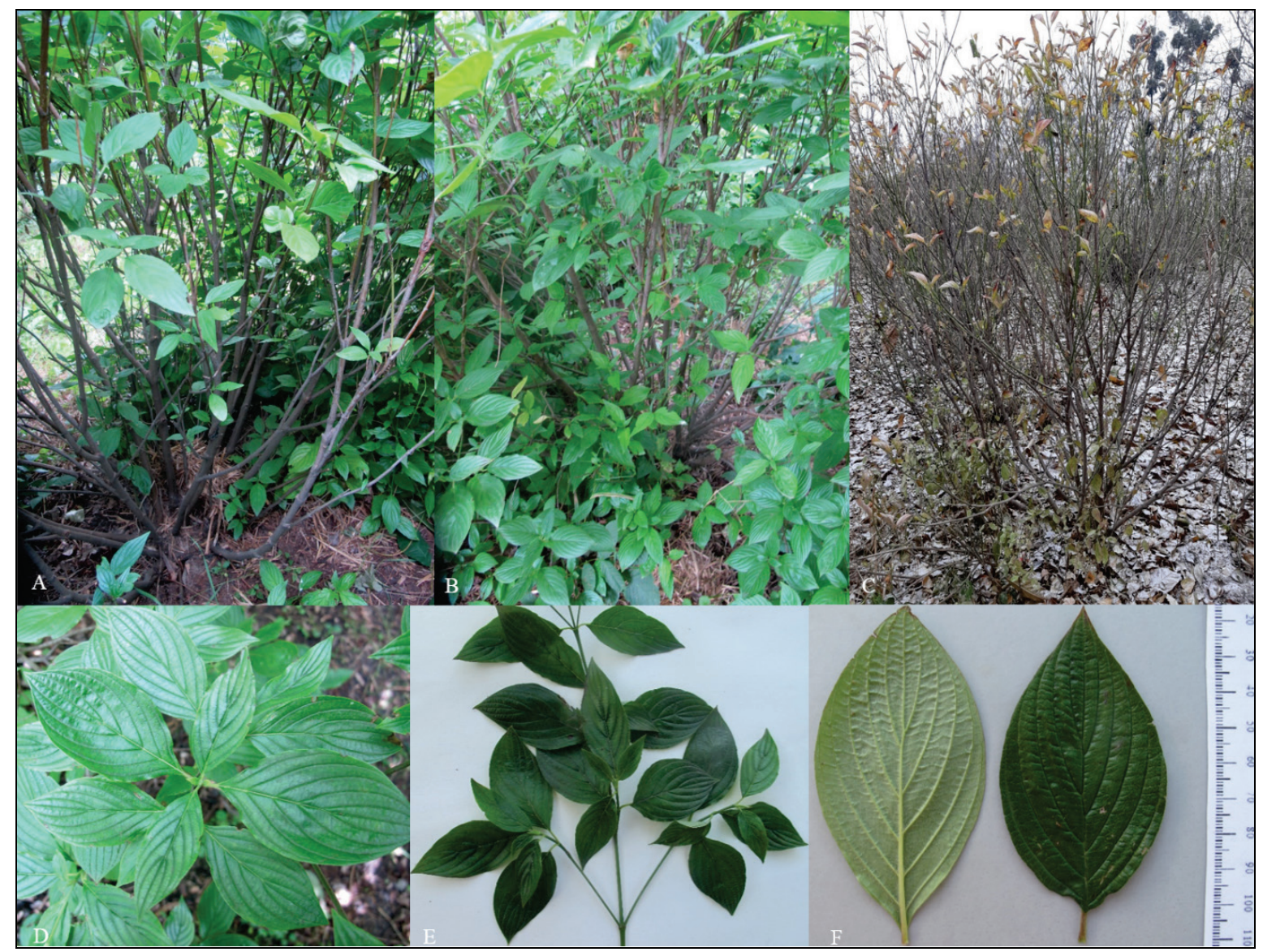

Fig. 1. Cornus sessilis Torr. ex Durand in M. M. Gryshko National Botanical Garden:

$A, B-10$ year old plant in summer; $C-10$ year old plant in autumn; $D, E$-shoot with leaves; $F$-leaves

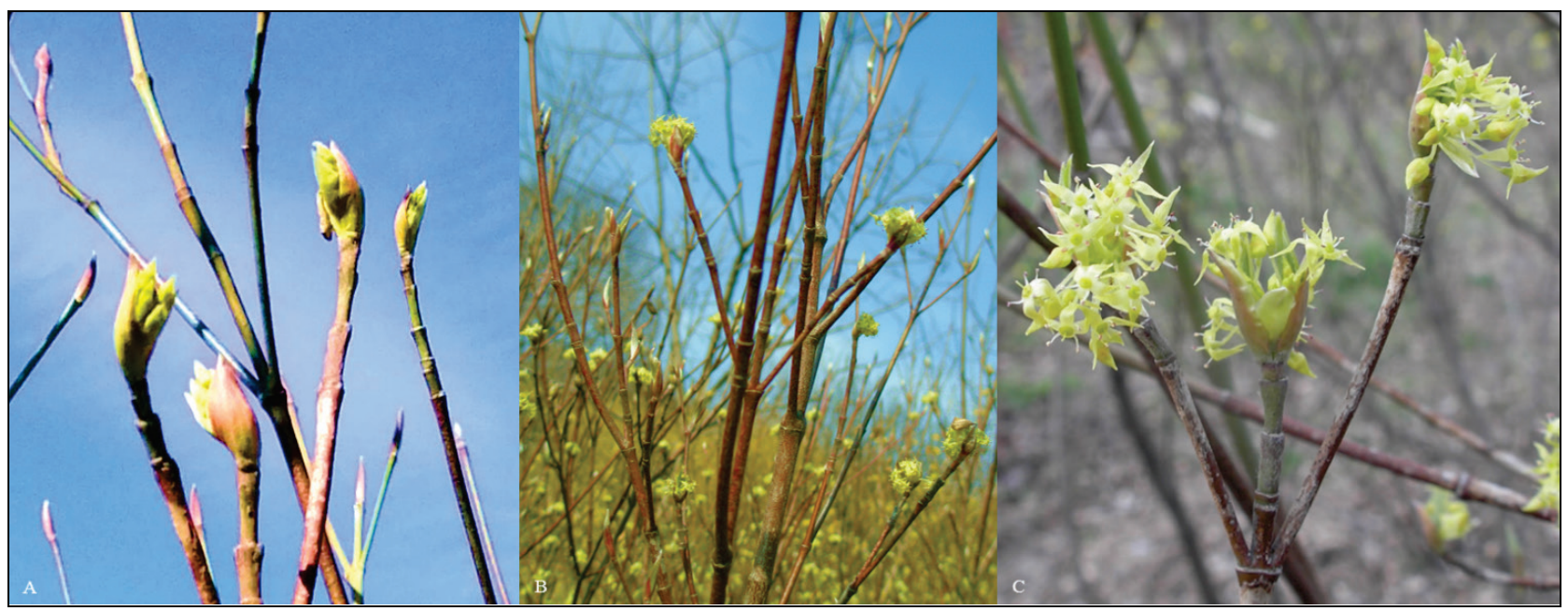

Fig. 2. The beginning of the growing season Cornus sessilis Torr. ex Durand.: $A$-blooming flower buds; $B, C$-flowering 


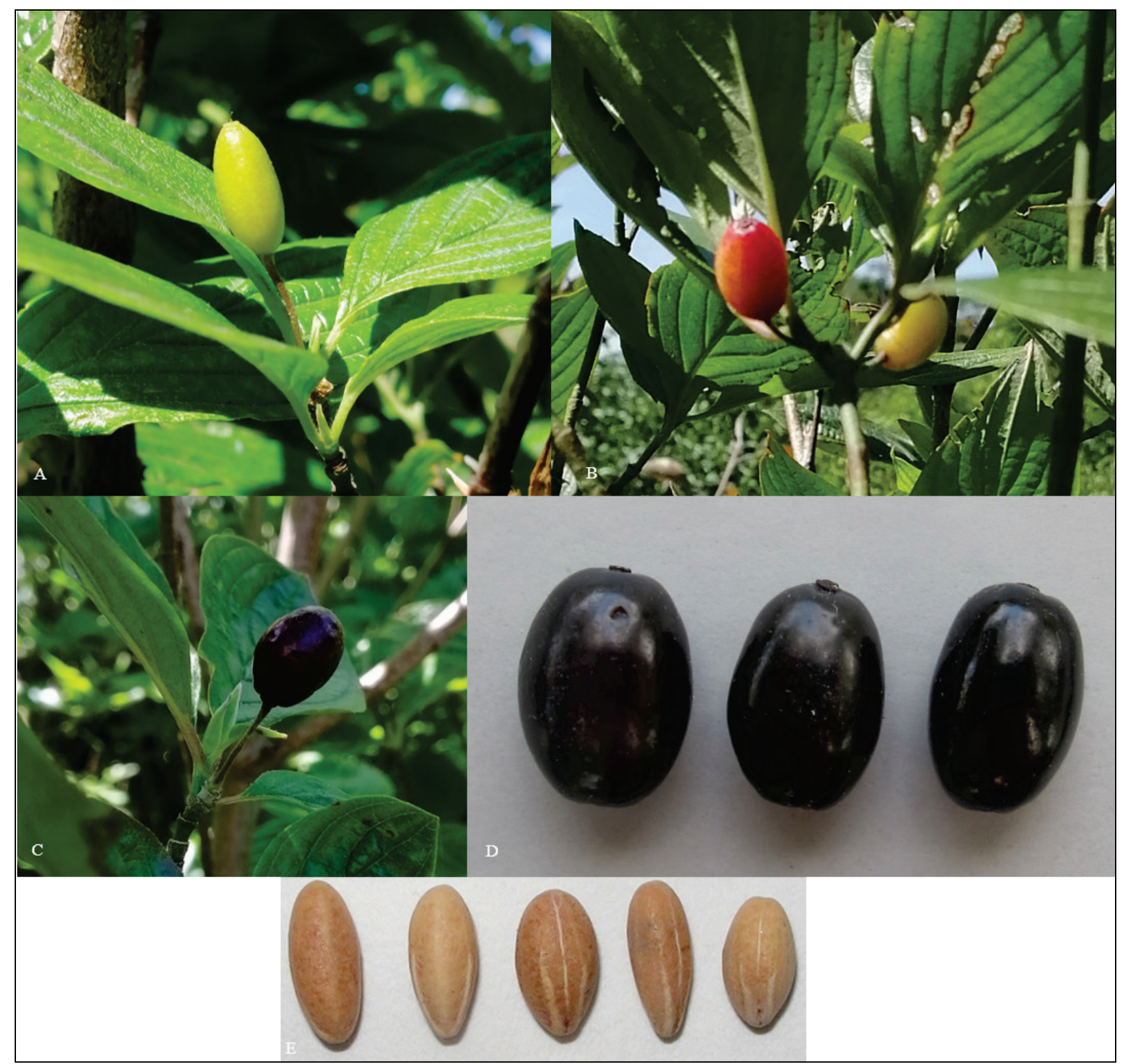

Fig. 3. Dynamics of fruits ripening Cornus sessilis Torr. ex Durand $(A-C)$, fruits $(D)$ and endocarps $(E)$

We studied the main phenophases of the plants: budbreak, flowering time, expansion and maturation of leaves, fruiting period, continuation of vegetation and leaves abscission during the 2019 growing season according to the generally accepted methods (Koch et al., 2007; Denny et al., 2014). We recorded the phases of the plant development visually and by periodic photography.

\section{Results}

Biometric parameters of leaves and fruits (Table 2, Fig. 5). The mean size of the leaf blade is $7.7 \times 3.8 \mathrm{~cm}$, of the petiole $-0.9 \mathrm{~cm}$. The length and width of the leaf blades are characterized by an average level of variability $(\mathrm{CV}=15.1 \%$ and $14.5 \%$, respectively), the length of petioles has a high level $(\mathrm{V}=21.4 \%)$. The fruits of the studied plants are small, with the mean size of $10.5 \times 6.8 \mathrm{~mm}$, the level of variability is average. The biggest fruits of the studied plants were of the size $12.0 \times 7.2 \mathrm{~mm}$. According to our data, the mean weight of the fruit is $0.41 \mathrm{~g}$, endocarp $-0.09 \mathrm{~g}$.

Seasonal rhythm of plant development (Table 3, Fig. 4). Certain phenological phases of the development of $C$. sessilis, as well as other plants, occur when the accumulation of the corresponding amounts of active and effective temperatures (Table 3). In 2019, the spring development of C. sessilis began in the conditions of significant fluctuations in average daily temperature from -2.2 to $+10.7{ }^{\circ} \mathrm{C}$. The first visually noticeable period of the plant development, deployment of generative buds, began in March, when the mean daily temperature was less than the biological minimum $\left(+5^{\circ} \mathrm{C}\right)$.

\section{Table 2}

Biometric parameters of leaf, fruit and endocarp Cornus sessilis Torr. ex Durand

\begin{tabular}{|c|c|c|c|c|c|c|c|c|c|}
\hline \multirow[b]{2}{*}{$\begin{array}{l}\text { Para- } \\
\text { meters }\end{array}$} & \multicolumn{3}{|c|}{ Leaf } & \multicolumn{3}{|c|}{ Fruit } & \multicolumn{3}{|c|}{ Endocarp } \\
\hline & $\begin{array}{c}\text { Petiole, } \\
\text { mm }\end{array}$ & $\begin{array}{r}\begin{array}{r}\text { Leaf b } \\
\mathrm{mr}\end{array} \\
\text { length }\end{array}$ & $\begin{array}{l}\text { ade, le } \\
\text { vidth }\end{array}$ & $\begin{array}{l}\text { length, di } \\
\mathrm{mm}\end{array}$ & $\begin{array}{l}\text { liameter, } \\
\mathrm{mm}\end{array}$ & $\begin{array}{l}\text { weight, } \\
\mathrm{g}\end{array}$ & $\begin{array}{l}\text { length, } \\
\mathrm{mm}\end{array}$ & $\begin{array}{l}\text { diameter } \\
\mathrm{mm}\end{array}$ & $\begin{array}{c}\text { weight, } \\
\mathrm{g}\end{array}$ \\
\hline $\mathrm{N}$ & 35 & 35 & 35 & 6 & 6 & 6 & 6 & 6 & 6 \\
\hline $\mathrm{x} \pm \mathrm{SD}$ & $\begin{array}{l}9.2 \pm \\
0.2 *\end{array}$ & $\begin{array}{c}77.1 \pm \\
1.2\end{array}$ & $\begin{array}{c}38.0 \pm \\
0.6\end{array}$ & $\begin{array}{c}10.5 \pm \\
0.9\end{array}$ & $\begin{array}{c}6.8 \pm \\
0.3\end{array}$ & $\begin{array}{c}0.41 \pm \\
0.06\end{array}$ & $\begin{array}{c}9.4 \pm \\
0.7\end{array}$ & $\begin{array}{c}4.6 \pm \\
0.5\end{array}$ & $\begin{array}{c}0.09 \pm \\
0.008\end{array}$ \\
\hline $\begin{array}{l}\min - \\
\max \end{array}$ & $\begin{array}{l}7.0- \\
14.0\end{array}$ & $\begin{array}{l}5.6- \\
10.4\end{array}$ & $\begin{array}{c}2.7- \\
5.3\end{array}$ & $\begin{array}{l}9.6- \\
12.0\end{array}$ & $\begin{array}{c}6.5- \\
7.2\end{array}$ & $\begin{array}{c}0.33- \\
0.49\end{array}$ & $\begin{array}{l}8.6- \\
10.4\end{array}$ & $\begin{array}{c}4.1- \\
5.5\end{array}$ & $0.08-0.1$ \\
\hline $\mathrm{V}, \%$ & 21.4 & 15.1 & 14.5 & 8.4 & 4.0 & 13.6 & 7.8 & 11.2 & 8.5 \\
\hline
\end{tabular}

Notes: $\mathrm{N}$ - number of measurements $\mathrm{x} \pm \mathrm{SD}$ - mean and standard deviation, min minimum value; max - maximum value; $\mathrm{CV}, \%$ - coefficient of variation; * - the distribution is not significantly normal (Shapiro-Wilk test, $\mathrm{W}=0.89, \mathrm{P}<0.05$ ).

This was facilitated by rather high maximum daily temperatures in March as a result of which the average monthly temperature exceeded the norm almost 10 times (Table 3, Fig. 4). According to the meteorological 
records (Weather in Kiev: https://rp5.ua/Weather_in Kiev, Zhuliany (airport)) the temperature was lower than the biological minimum only in the first decade of the month. During the remaining period, it was higher than $+5^{\circ} \mathrm{C}$, on some days reaching $+16.5-19.1^{\circ} \mathrm{C}$. The flowering period of $C$. sessilis plants in the NBG began in the last days of March and lasted almost two weeks (Table 3). Throughout the period, the minimum temperature and amount of effective temperatures were higher compared to the biological minimum, due to which the plants had many generative buds. In each inflorescence, we observed 7 to 13 flowers. But most of the ovaries fell in the beginning of June, leaving 2-3 to 5-7 in each inflorescence.

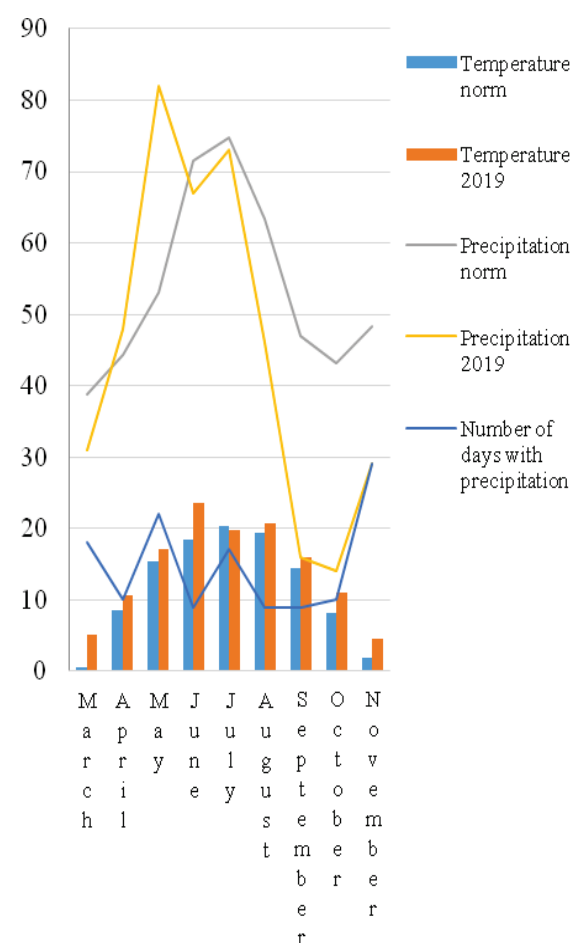

Fig. 4. The average month temperature $\left({ }^{\circ} \mathrm{C}\right)$, precipitation $(\mathrm{mm})$ and number of days with precipitation in Kyiv in 2019

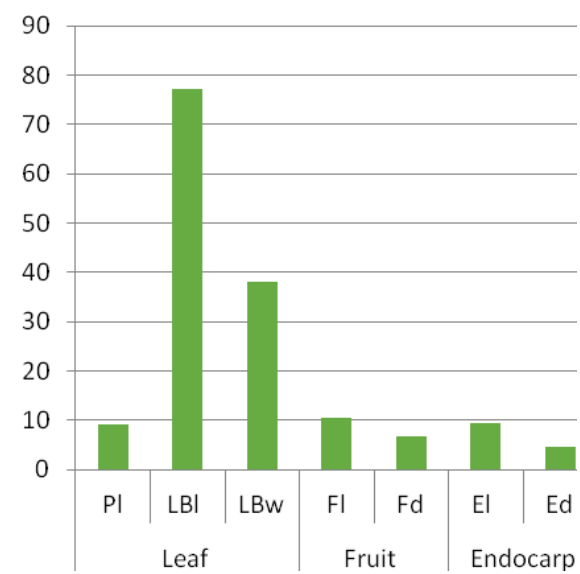

Fig. 5. Morphometric characteristic of leaf, fruit and endocarp Cornus sessilis Torr. ex Durand: $\mathrm{Pl}$ - petiole length; $\mathrm{LBl}$ - leafblade length; $\mathrm{LBw}$ - leaf blade width; $\mathrm{Fl}$ - fruit length; $\mathrm{Fd}$-fruit diameter; $\mathrm{El}$ - endocarp length; $\mathrm{Ed}$ - endocarp diameter

The development and maturation of the leaves and the growth of vegetative shoots, began at the end of the flowering when the last flowers in the inflorescence opened. At the end of the first decade of July, most annual shoots with mature leaves usually had four internodes $5-11 \mathrm{~cm}$ in length. The proximal internodes were the longest. In parallel with the growth of shoots, the fruits developed and increased in size. Fruit ripening began in the second decade of July. The average daily temperature in this period ranged +15.4 to $+23.2^{\circ} \mathrm{C}$, and the sum of the effective temperatures equaled $1,272.0^{\circ} \mathrm{C}$ to $1,681.3^{\circ} \mathrm{C}$.
Table 3

Seasonal rhythm of plant development Cornus sessilis Torr. ex Durand

\begin{tabular}{lccc}
\hline \multicolumn{1}{c}{ Phenological phases } & $\begin{array}{c}\text { Calendar } \\
\text { duration }\end{array}$ & $\Sigma_{\text {act }}{ }^{\circ} \mathrm{C}^{*}$ & $\Sigma_{\text {eff }} \mathrm{t}^{\circ} \mathrm{C}^{*}$ \\
\hline Bud development & $01.03-29.03$ & $0.0-98.1$ & $0.0-27.8$ \\
Flowering & $30.03-15.04$ & $106.3-237.1$ & $31.3-101.5$ \\
Leaf development and shoots & $16.04-10.07$ & $252.5-1864.9$ & $103.1-1260.6$ \\
formation & $11.07-08.08$ & $1880.3-2430.6$ & $1272.0-1681.3$ \\
Ripening of fruit & $09.08-19.09$ & $2450.7-3275.3$ & $1696.4-2316.0$ \\
Continuation of growing season & $20.09-15.10$ & $3283.7-3571.4$ & $2319.4-2486.9$ \\
\hline Leaf fall
\end{tabular}

Note: * - biological zero point $+5^{\circ} \mathrm{C}$; active and effective temperatures are given at the beginning and end of each phenophase.

The drupes first became yellow, then red and only then acquired their purple-black colour, which is why the species was called cornel miner or cornel chokeberry. The fruits of $C$. sessilis have a bitter-sweet taste. The same inflorescence may have drupes that are at the different stages of maturity. The number of fruits was gradually decreasing throughout the ripening process. Only a few drupes had reached full maturity. June 2019 marked by the higher than normal average monthly temperature and lower than normal amount of precipitation (Fig. 4). Vegetation of plants continued until the second decade of September. During this period, the plants formed the buds to recover the following year.

Drought and the high average monthly temperature which was observed in the second half of summer and autumn 2019, led to premature and atypical leaf fall. The leaves on the perennial branches of plants began to fall in mid-September at a sum of the effective temperatures of $2319.4{ }^{\circ} \mathrm{C}$ (Table 3 ). In the second decade of October only a few leaves remained on the annual shoots. In general, the seasonal development cycle of C. sessilis plants cultivated in the NBG in 2019 lasted 229 days (Fig. 6).

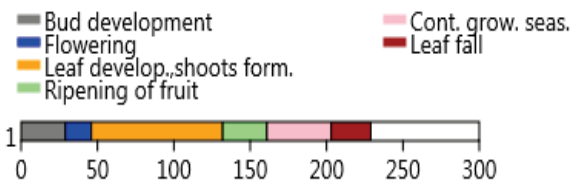

Fig. 6. Phenospectrum of the seasonal rhythm of Cornus sessilis Torr. ex Durand plant development in 2019 (Kyiv, the NBG): number of days from March 1; Leaf develop., shoots form. - leaf development and shoots formation; Cont. grow. seas. - continuation of the growing season; $1-$ phenological phases

\section{Discussion}

Cornus sessilis was described in 1855 by two herbarium collections (Durand, 1855). The first was dated 1851 and collected on the banks of Deer Creek,- a tributary of the Sacramento River (California, USA) by Henry Pratten, a geologist and paleontologist of the State Geological Survey of Illinois, who studied the geology of California (https://faculty.evansville.edu/ck6/bstud/pratten.html). The second one was collected by J. M. Bigelow, surgeon and botanist to the expedition of Lieutenant A. W. Whipple (1853-1854) exploring the area from the Mississippi River to the Pacific Ocean near the 35th parallel of Northern latitude. Elements of the typical material are stored in three herbariums, including the New York Botanical Garden: samples of J. M. Bigelow collection (near Grap Valley, barcode 2505696) and H. N. Bolander (s.n., Forest Hill, barcode 2505699); Harvard University Herbaria \& Libraries (barcode 00075359, specimen by four authors are mounted on one sheet: H. N. Bolander 4555, H. Mann, Dr. J. M. Bigelow and H. Pratten); and Herbarium of the Muséum National d'Histoire Naturelle (sheet with specimens from the two collections, barcode P04539375). The herbarium housed in the National Museum of Natural History (MNHN) is a part of the collection donated by E. M. Durand in 1868 to the Herbier Muséum Paris (https://collections.nlm.nih.gov/catalog/nlm:nlmuid-101200035-bk). Durand noted in the protolog that Henry Pratten's collection in the vicinity of Nevada, a place situated on Deer Creek, one of the affluents of the Sacramento river (1851), was crucial to the description of the species. 
He received it as a part of the collection of the Philadelphia Academy of Natural Sciences in late 1854. The study of this specimen made it possible to complete and publish the description of the species. Plants grown in the NBG are identical to those described in the literature and depicted on the digitized herbarium specimens. They appear healthy, are optimally developed, having dense foliage and well-developed leaves, they grow intensively. There are no significant signs of diseases or injuries, either mechanical or from pests.

Morphological descriptors reflect not only genetically determined and evolutionarily determined factors, but also the response of the plant to certain living conditions in specific localities (Henry, 2005; Belyakov et al., 2017; Lykholat et al., 2017; Gritsan et al., 2019; Horčinová Sedláčková et al., 2019). They are widely used to control the condition of plants at all stages of introduction - from the initial testing to the "complete" acclimatization and naturalization of new species and varietal testing, as well as to preserve plant biodiversity of aboriginal and global floras (Primack \& Miller-Rushing, 2009; Krishnan \& Novy, 2016; Faraji \& Karimi, 2020). They are also important for biological control of global climate change. Living collections of introduced plants and controlled growing conditions make it possible to widely use qualitative and quantitative indicators to capture the adaptation process of species to new living conditions.

Our study showed that the morphological features (life form, colour and texture of the bark, leaf shape, pubescence, structure of generative and vegetative buds, inflorescences, flowers, fruits, endocarp) studied in conditions of introduction of $C$. sessilis plants are identical to those given in literature (Durand, 1855; Weaver, 1976; Eyde, 1988; Murrell \& Poindexter, 2016).

There are no data on a detailed statistical analysis of the size of $C$. sessilis leaves and fruits in the literature. We are the first to provide them (Table 2, Fig. 5). The differences relate mainly to the biometric parameters of the leaf and fruit. The plants introduced to the NBG had larger leaves compared ith the wild plants of the species. Variation of the petiole length was in the the interval of 7.0-14.0 vs. $5.0-10.0 \mathrm{~mm}$, the length and width of the leaf blades $-5.6-10.4 \times 2.7-5.3 \mathrm{~cm}$ vs. $4.0-9.0 \times 2.0-4.0 \mathrm{~cm}$, respectively (Murrell \& Poindexter, 2016). The larger size of the leaves of C. sessilis plants grown in the NBG as compared to wild plants in California (USA) is likely due to the better water supply of the first stages of growth and development of leaves. Precipitation in Kyiv falls throughout the year, including July, when the next year buds are formed. In the region where $C$. sessilis is described (on the example of the city of Sacramento), precipitation falls mostly in winter while in July it is practically absent (Table 1). Formation of the small leaves is also caused by an acidic substrate, which is characteristic for the natural ecotopes of the species. The mesomorphic nature of the leaves is confirmed by their anatomical structure. On the plants of $C$. sessilis from the NBG, Klymenko \& Klymenko (2017) have for the first time studied the anatomical structure of leaves in comparison with those of other species of Cornus s. 1. and identified distinctive anatomical features of their leaves: dorsoventral type of the structure, slight thickness, membranous adaxial and indistinctly folded abaxial cuticle, adaxial and abaxial epidermis which were different in thickness, average coefficient of palisade, average coefficient of elongation of palisade cells, large volume of intercellular spaces, little stomata per unit area of the leaf. The authors showed also that the studied species of Cornaceae in the NBG were placed as follows according to the degree of mesomorphism of their leaves and their adaptive anatomical and ecological specificity: Cornus sessilis - Swida sanguinea (L.) Opiz - Cornus mas - Cynoxylon kousa (Bürger ex Hance) Nakai - Cynoxylon florida Raf. Cornus officinalis. Therefore, the leaves of $C$. sessilis are the most mesomorphic, which reflects the species' high demands on the humidity of habitats. In 2019, only six fully developed fruits reached full maturity. Most fruits shed at the different stages of development due to the drought in the second half of July and August. In July, the total monthly precipitation was close to the norm, $73.0 \mathrm{~mm}$, but half of it, $36.0 \mathrm{~mm}$, fell in one day, on the 14th of July 2019 (https://rp5.ua/Weather_in_Kiev,_Zhuliany). In August, the precipitation was much lower than normal. In the region of its natural distribution, the species exist in the ecotopes of wet ravines, river banks and wetlands. Under such conditions, the root system is partially provided with moisture, despite the high air temperature and lack of precipitation. In the NBG, the place of growth of the species is drier com- pared to the natural ecotopes, which has a particularly negative effect on its root system. Probably, the drought may be the cause of the smaller sizes of the fruits of $C$. sessilis plants in the conditions of introduction than in the wild plants: $9.6-12.0 \times 6.5-7.2 \mathrm{~mm}$ vs $10.0-15.0 \times 5.0-7.5 \mathrm{~mm}$, respectively. The interval of variation in fruit size is slightly shifted to the smaller side as compared to such in wild plants (Murrell \& Poindexter, 2016). In the wild plants, the largest fruits were $15.0 \times 7.5 \mathrm{~mm}$, whereas ours $-12.0 \times 7.2 \mathrm{~mm}$. The maximum length and diameter of the endocarp and the intervals of its variation in the studied plants were also smaller compared with those in the plants of the natural habitats. The length of the endocarp has a smaller range of variation than that of wild individuals of the species, and the corresponding parameter of its diameter is almost the same as known from the literature (Murrell \& Poindexter, 2016). Data on weight of the fruit and the endocarp of $C$. sessilis are not available in the literature (Table 2). We identified them for the first time. The mean weight of the fruit is characterized by medium levels of variability and the endocarp by low levels of variability (Mamayev, 1975).

The results of our study made it possible to expand and supplement the morphological characteristic of the species.

Deciduous shrubs or trees are 1.8-2.2 m tall. The root system is superficial. It has single or multiple stems, ranging $19.5-147.0 \mathrm{~cm}$ in height and two to three centimeters in diameter; greyish-brown, orange or orange-brown bark, which peels off on the stems; burgundy, brown or red branches, densely covered with lentils; green young twigs densely pressed-pubescent. Generative buds are terminal, pubescent with short yellowish-brown hairs, vegetative buds are terminal or axillary, solitary or combined with the generative ones. Leaves have short petioles, $7.0-14.0 \mathrm{~mm}$, their base is extended and semiamplexicaul; leaf blades are elliptical, 5.6$10.4 \times 2.7-5.3 \mathrm{~cm}$, with cuneate base and acute or short acuminate apex, adaxial surface green or dark green, sparsely appressed-hairy, abaxial surface grey-green or yellow-green, appressed-hairy, with tufts of erect hairs in axils of secondary veins; 4-5 lateral largest veins per side. Inflorescences are small-flowered; the inflorescence axis is $0-1 \mathrm{~mm}$ long; with yellowish or brown bracts, lanceolate with acute apex $0.5-1.0 \mathrm{~cm}$ long; free peduncles dilated at the top. Flowers: narrow-conical, pubescent hypanthium; sepals $0.1-0.5 \mathrm{~mm}$ long; greenish-yellow lanceolate petals 3$4 \mathrm{~mm}$ long. Drupes ellipsoidal, 9.6-12.0 $\times 6.5-7.2 \mathrm{~mm}$, weighing $0.3-$ $0.5 \mathrm{~g}$; in the process of maturation their colour changes from green to yellow, red, then purple-black; endocarp is widely fusiform with two lateral grooves, $8.6-10.4 \times 4.1-5.5 \mathrm{~mm}$, weight $0.08-0.10 \mathrm{~g}$.

The seasonal rhythm of plant development has long been used as an indicator of the influence of climatic factors. It also reflects the adaptive capacity of plants in the new living conditions (Shumik et al., 2016; Valencia et al., 2016; Richardson, 2018). Seasonal changes in plant dynamics are some of the strongest biotic signals of climate change, which manifests at all levels of living organization - from biome to intraspecific. Therefore, the area of use of the phenological spectrum has been gradually expanding in modern research, primarily due to the global climate change (Richardson et al., 2013; Anderson, 2016; Tang et al., 2016; Mason et al., 2020).

The response of the plants to the periodic (seasonal) changes in climatic conditions is an integral part of studies of the introduction, adaptive and acclimatizing ability of plants, especially the new non-traditional species, as well as the selection of new cultivars and forms of plants (Koch et al., 2007; Denny et al., 2014; Shumik et al., 2016). A detailed study of the complete cycle of $C$. sessilis phenorhythm, as such, has not yet been performed. There are very general data about the flowering and fruiting period of the plants in their homeland: March to June and August to September, respectively (Murrell \& Poindexter, 2016). In the climatic conditions of the NBG, $C$. sessilis plants have undergone a full cycle of seasonal development (Fig. 4) and preserved, in general, the phenological strategy inherent in its natural ecotopes.

The flowering period of the plants of this species in the climatic conditions of the NBG is close to the similar period of C. mas, many cultivars and forms of which are cultivated successfully in botanical gardens (Klimenko, 1990). In 2019, flowering of $C$. sessilis in the NBG began on March 30 (Table 3). At the beginning of the flowering, the sum of the effective temperatures was small $\left(31.3{ }^{\circ} \mathrm{C}\right)$, but in March of that year sharp differences between the low nighttime and the high daytime temperatures were often observed. As a result, the average monthly tempera- 
ture significantly exceeded the norm (Fig. 2). According to our data, the early cultivars of $C$. mas bloomed together with $C$. sessilis. Note that during 1976-1988, the average date of the beginning of flowering of $C$. mas plants was April 8-15. The average sum of the effective temperatures at this time was $55.0-69.0^{\circ} \mathrm{C}$. Only in 1983 the plants bloomed on March 27, when the sum of the effective temperatures was $38.0^{\circ} \mathrm{C}$ (Klimenko, 1990).

The ripening period of the fruit lasted 29 days. The drupes became first yellow, after a while red, and then black. This feature clearly distinguishes $C$. sessilis from the other species of the genus. Few fruits have reached the period of full maturity. This phenomenon is associated, perhaps, with the self-sterility as the biological characteristic of the species, as well as with the weather conditions of this period.

The growing season of $C$. sessilis in 2019 lasted 229 days. For comparison, the same period of $C$. mas in 1980-1988 lasted 190-198 days (Klymenko, 1990). During 2000-2016, the average duration of its growing season increased to 220 days. The average sum of the effective temperatures at the beginning of flowering was higher $\left(62.8^{\circ} \mathrm{C}\right)$ (Klimenko et al., 2016). Note that this dynamic of vegetation duration of $C$. mas is consistent with the results of phenological observations within the framework of the International Phenological Gardens, a project launched in 1957 and based at the Institute of Crop Sciences at Humboldt University in Berlin (Chmielewski, 1996; Menzel \& Fabian, 1999; Menzel, 2000; Chmielewski \& Rotzer, 2001; Primack \& Miller-Rushing, 2009). The authors of the project found out that the growing season of the studied plants, especially shrubs, increased almost 11 days during 50 years (1959-2009) (Menzel, 2000). Thus, we assume that the longer growing season of C. mas reflects the effects of climate change in Ukraine over the last two decades. During this period, the droughts intensified in Ukraine both in their intensity and frequency (occurring on average once every three years) (Fileccia et al., 2014). The first dead leaves on $C$. sessilis were seen in the last decade of September, and the leaf fall ended in mid-October. We assume that such of the leaf fall as in 2019 is not typical. It was caused by a significant drought and the high temperatures in late summer and autumn (Fig. 4). In C. mas plants, for example, the average date when leaves began to fall is October 20, which is later than in C. sessilis in 2019 (September 20). Thus, the longer vegetation period of $C$. sessilis (229 days) compared to C. mas is due to its ability to begin development in early spring and at the lower amount of the effective temperatures, which is due to its life in the Mediterranean (California) climate.

\section{Conclusions}

We have carried out the initial testing of the plants of the little-studied and little-known California's endemic $C$. sessilis, introduced in the NBG. The morphological descriptors (life form, colour and texture of bark, leaf shape, pubescence character, the structure of generative and vegetative buds, inflorescences, flowers, fruits, endocarps) of $C$. sessilis plants grown in NBG are identical to those of the natural biotope plants. We have determined the weight of fruits $(0.33-0.49 \mathrm{~g})$ and the endocarp $(0.08-0.10 \mathrm{~g})$ for the first time and have performed a biometric analysis of the leaves and the fruits size. The plants grown in the NBG, compared to the wild plants, had larger leaf blades $(5.6-10.4 \times 2.7-5.3 \mathrm{~cm}$ vs. $4.0-9.0 \times 2.0-4.0 \mathrm{~cm})$, but smaller fruits $(9.6-12.0 \times 6.5-7.2 \mathrm{~mm}$ vs. $10.0-15.0 \times 5.0-7.5 \mathrm{~mm})$. We have in-detail studied the main phenophases of $C$. sessilis for the first time and found out that the plants in the NBG have undergone a full cycle of seasonal development (from the deployment of buds to the leaf fall, inclusive) during 229 days. The phenological strategy of $C$. sessilis introduced into the NBG corresponds to that of other species of Cormus s. str., in particular, wild plants and the C. mas plants introduced to the NBG consequently, the species may exist in the temperate climate of Ukraine. The state of moisture supply of the substrate through the superficial root system of plants of this species requires control.

\section{References}

Anderson, J. T. (2016). Plant fitness in a rapidly changing world. New Phytologist, 210(1), 81-87.

Atkinson, B. A., Stockey, R. A., \& Rothwell, G. W. (2016). Cretaceous origin of dogwoods: An anatomically preserved Cornus (Cornaceae) fruit from the Campanian of Vancouver Island. PeerJ, 4, e2808.
Belyakov, S. O., Gofman, O. P., \& Vyshenska, I. G. (2017). Modelling the dynamics of total precipitation and aboveground net primary production of fescue-feather grass steppe at Askania Nova according to global climate change scenarios. Biosystems Diversity, 25(1), 16-24.

Chmielewski, F.-M. (1996). The international phenological gardens across Europe. Present state and perspectives. Phenology and Seasonality, 1, 19-23.

Denny, E. G., Gerst, K. L., Miller-Rushing, A. J., Tierney, G. L., Crimmins, T. M., Enquist, C. A., Guertin, P., Rosemartin, A. H., Schwartz, M. D., Schwartz, M. D., \& Weltzin, J. F. (2014). Standardized phenology monitoring methods to track plant and animal activity for science and resource management applications. International Journal of Biometeorology, 58(4), 591-601.

Durand, E. (1855). Plantae prattenianae californicae: An enumeration of a collection of California plants, made in the vicinity of Nevada, by Henry Pratten, Esq., of New Harmony; with critical notices and descriptions of such of them as are new, or yet unpublished in America. Journal of the Academy of Natural Sciences of Philadelphia, 2(3), 79-104.

Eyde, R. H. (1988). Comprehending Cornus: Puzzles and progress in the systematics of the dogwoods. The Botanical Review, 54(3), 233-351.

Faraji, L., \& Karimi, M. (2020). Botanical gardens as valuable resources in plant sciences. Biodiversity and Conservation, 29(1), 1-22.

Fileccia, T., Guadagni, M., Hovhera, V., \& Bernoux, M. (2014). Ukraine: Soil fertility to strengthen climate resilience. Preliminary assessment of the potential benefits of conservation agriculture. Food and Agriculture Organization of the United Nations, Rome.

Gritsan, Y. I., Sytnyk, S. A., Lovynska, V. M., \& Tkalich, I. I. (2019). Climatogenic reaction of Robinia pseudoacacia and Pinus sylvestris within Northern Steppe of Ukraine. Biosystems Diversity, 27(1), 16-20.

Hammer, Ø., Harper, D. A. T., \& Ryan, P. D. (2001). PAST: Paleontological statistics software package for education and data analysis. Palaeontologia Electronica, 4(1), 1-9.

Henry, R. J. (Ed.). (2005). Plant diversity and evolution. Genotypic and phenotypic variation in higher plants. CABI Publishing, Wallingford.

Horčinová Sedláčková, V., Grygorieva, O., Vergun, O., Vinogradova, Y., Brindza, J. (2019). Comparison of selected characteristics of cultivarsand wild-growing genotypes of Sambucus nigra in Slovakia. Biosystems Diversity, 27(1), 399-404.

Klimenko, S. (2004). The comelian cherry (Cornus mas L.): Collection, preservation, and utilization of genetic resources. Journal of Fruit and Ornamental Plant Research, 12, 93-98.

Klimenko, S. V. (1990). Kizil na Ukraine [Comelian cherry in Ukraine]. Naukova Dumka, Kiev (in Russian).

Klimenko, S. V., Kustovska, A. V., Grygorieva, O. V., \& Teslyuk, M. G. (2016). Vidy semeystva Cornaceae Bercht. \& J. Presl dlya dekorativnogo sadovodstva [Species of family Cornaceae Bercht. \& J. Presl for ornamental horticulture]. Indigenous and Introduced Plants, 12, 89-95 (in Russian).

Klymenko, S., \& Klymenko, O. (2017). Leaf anatomy of the members of Cornaceae family in conditions of the Forest-Steppe of Ukraine. Annals of the Romanian Society for Cell Biology, 21(2), 28-39.

Klymenko, S., Grygorieva, O., \& Onyshuk, L. (2017). Biological bases of seed and vegetative reproduction of cornelian cherry (Cornus mas L.) in nature and culture. Agrobiodiversity for Improving Nutrition, Health and Quality, 1, 233-248.

Klymenko, S., Kucharska, A. Z., Sokół-Łętowska, A., \& Piórecki, N. (2019). Antioxidant activities and phenolic compounds in fruits of cultivars of cornelian Cherry (Cornus mas L.). Agrobiodiversity for Improving Nutrition, Health and Life Quality, 3, 484499.

Koch, E., Bruns, E., Chmielewski, F. M., Def, C., Lipa, W., \& Menzel, A. (2007). Guidelines for plant phenological observations. World Climate Data and Monitoring Programme. WMO, Geneva.

Kondratyuk, E. N., \& Ostapko, V. M. (1990). Redkiye, endemichnyye i reliktovyye rasteniya yugo-zapadnoy Ukrainy v prirode i kul'ture [Rare, endemic and relict plants of southwestern Ukraine in nature and culture]. Naukova Dumka, Kiev (in Russian).

Krishnan, S., \& Novy, A. (2016). The role of botanic gardens in the twenty-first century. CAB Reviews, 11(23), 1-10.

Lykholat, Y. V., Khromykh, N. A., Ivan'ko, I. A., Matyukha, V. L., Kravets, S. S., Didur, O. O., Alexeyeva, A. A., Shupranova, L. V. (2017). Assessment and prediction of the invasiveness of some alien plants in conditions of climate change in the steppe Dnieper region. Biosystems Diversity, 25(1), 52-59.

Mamayev, S. A. (1975). Osnovnyye printsipy metodiki issledovaniya vnutrividovoy izmenchivosti drevesnykh rasteniy [The main principles of the methodology for the study of intraspecific variability of woody plants]. In: Individual and ecological-geographic variability of plants. Ural Worker, Sverdlovsk. Pp. 3-14 (in Russian).

Manchester, S. R., Xiang, X. P., \& Xiang, Q. Y. (2010). Fruits of comelian cherries (Comaceae: Cornus subg. Cornus) in the Paleocene and Eocene of the Northern Hemisphere. International Journal of Plant Sciences, 171(8), 882-891.

Mason, C. M., La Scaleia, M. C., De La Pascua, D. R., Monroe, J. G., \& Goolsby, E. W. (2020). Learning from dynamic traits: Seasonal shifts yield insights into 
ecophysiological trade-offs across scales from macroevolutionary to intraindividual. International Journal of Plant Sciences, 181(1), 88-102.

Menzel, A. (2000). Trends in phenological phases in Europe between 1951 and 1996. International Journal of Biometeorology, 44(2), 76-81.

Menzel, A., \& Fabian, P. (1999). Growing season extended in Europe. Nature, 397(6721), 659-659.

Murrell, Z. E., \& Poindexter, D. B. (2016). Cornaceae Bercht. \& J. Presl. In: Flora of North America Editorial Committee (Eds.). Flora of North America North of Mexico. Magnoliophyta: Vitaceae to Garryaceae. Oxford University Press, New York and Oxford.

Osadchyy, V. I., Kosovets, O. O., \& Babichenko, V. M. (Eds.). (2010). Klimat Kyieva [Climate of Kyiv]. Nika Center, Kyiv (in Ukrainian).

Primack, R. B., \& Miller-Rushing, A. J. (2009). The role of botanical gardens in climate change research. New Phytologist, 182(2), 303-313.

Richardson, A. D. (2018). Tracking seasonal rhythms of plants in diverse ecosystems with digital camera imagery. New Phytologist, 222(4), 1742-1750.

Richardson, A. D., Keenan, T. F., Migliavacca, M., Ryu, Y., Sonnentag, O., \& Toomey, M. (2013). Climate change, phenology, and phenological control of vegetation feedbacks to the climate system. Agricultural and Forest Meteorology, 169, 156-173.

Shumik, N. I., Zaimenko, N. V., \& Ostapyuk, V. M. (2016). Sezonnaya ritmika introdutsirovannykh rasteniy kak kriteriy ikh ustoychivosti i adaptatsii [Seasonal rhythm of introduced plants as a criterion for their resistance and adaptation]. Bulletin of the Botanical Garden-Institute, 15, 96-98 (in Russian).

Tang, J., Köme, C., Muraoka H., Piao, S., Shen, M., Thackeray, S. J., \& Yang, X. (2016). Emerging opportunities and challenges in phenology: A review. Ecosphere, 7(8), e01436.
Valencia, E., Méndez, M., Saavedra, N., \& Maestre, F. T. (2016). Plant size and leaf area influence phenological and reproductive responses to warming in semiarid Mediterranean species. Perspectives in plant ecology, evolution and systematics, 21, 31-40.

Weaver, R. E. (1976). The cornelian cherries. Arnoldia, 36(2), 50-56.

Xiang, Q,-Y., \& Thomas, D. T. (2008). Tracking character evolution and biogeographic history through time in Cornaceae - does choice of methods matter. Journal of Systematics and Evolution, 46(3), 349-374.

Xiang, Q. Y. J., Thorne, J. L., Seo, T. K., Zhang, W., Thomas, D. T., \& Ricklefs, R. E. (2008). Rates of nucleotide substitution in Comaceae (Comales) - pattern of variation and underlying causal factors. Molecular Phylogenetics and Evolution, 49(1), 327-342.

Xiang, Q., \& Eyde, R. (1995). Documented chromosome numbers 1995:1. Chromosome number of Cornus sessilis (Comaceae): Phylogenetic affinity and evolution of chromosome numbers in Cornus. SIDA, Contributions to Botany, 16(4), 765-768.

Xiang, Q.-Y. J., Thomas, D. T., Zhang, W., Manchester, S. R., \& Murrel, Z. (2006). Species level phylogeny of the genus Cornus (Cornaceae) based on molecular and morphological evidence - implications for taxonomy and Tertiary intercontinental migration. Taxon, 55(1), 9-30.

Xiang, Q.-Y., Manchester, S. R., Thomas, D. T., Zhang, W., \& Fan, C. (2005). Phylogeny, biogeography, and molecular dating of cornelian cherries (Cornus, Cornaceae): Tracking tertiary plant migration. Evolution, 59(8), 1685-1700.

Yu, Y., Xiang, Q. Y., Mano, P. S., Soltis, D. E., Soltis, P. S., Song, B. H., Cheng, S. F., Liu, X., \& Wong, G. (2017). Whole-genome duplication and molecular evolution in Cornus L. (Comaceae) - insights from transcriptome sequences. PloS One, 12(2), e0171361. 